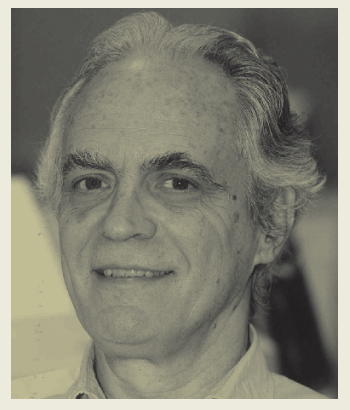

\title{
ECONOMIA E POLIITICA DESCOLARAM-SE?
}

É tentador afirmar que, no Brasil, a economia descolou-se da política. Enquanto a primeira recupera-se com a inflação abaixo do piso, o desemprego em queda, o produto interno bruto (PIB) saindo do negativo, a bolsa de valores batendo recordes e o dólar bem-comportado, a segunda naufraga na instabilidade causada pelas acusações de corrupção contra o presidente da República e seus ministros da "casa".

Mas tal descolamento é enganoso. Ao contrário, essas dimensões da vida de uma nação nunca estiveram tão entrelaçadas. Do lado da economia, alguns fatores externos somados a mudanças na política econômica ajudaram a (lenta) superação da recessão.

Taxas de juros muito baixas no plano internacional e melhores preços dos produtos de exportação produziram superávits recordes na balança comercial e entradas robustas de investimentos estrangeiros atraídos pelas concessões.

No plano interno, a contração do binômio inflação e taxa de juros - a primeira ajudada especialmente pela queda dos preços dos alimentos - somada à liberação do Fundo de Garantia do Tempo de Serviço (FGTS) inativo deram um alento ao consumo, expandindo a demanda. As empresas responderam usando sua capacidade ociosa para aumentar a produção sem investir em capital fixo. A queda dos salários também contribuiu para garantir lucros e proporcionar um PIB acima de zero depois de três longos anos, tendência reforçada recentemente com a aprovação da reforma trabalhista.

No entanto, essa recuperação baseada na expansão do consumo, isto é, na demanda, tem vida curta.
Se os investimentos em capital fixo (inclui novas tecnologias) não saírem da toca, o processo dificilmente se tornará sustentável. A questão é: quais as condições para que o investimento retorne de forma massiva em nossa economia? Qualquer investimento requer um prazo de maturação, o qual pode ser mais ou menos longo: três, cinco ou mais anos para gerar lucros e justificar a decisão de investir.

É necessário, portanto, que o investidor confie no futuro. Mas surge o enigma: quem será eleito em 2018? Qualquer candidato que ameace reverter os rumos da atual (impopular) política econômica, cuja espinha dorsal é o ajuste fiscal (teto dos gastos, reforma da previdência, etc.), torna-se disfuncional aos olhos dos donos do PIB. Hoje, o maior temor dos empresários é a volta de um governo populista, que desmonte a atual política econômica. Apenas um nome surge com cada vez mais solvência para tornar essa ameaça realidade: o do ex-presidente Lula. Tudo que contribua para inviabilizar sua candidatura, de delações premiadas de amigos íntimos até sentenças judiciais de segunda instância, dissolve a neblina de outubro de 2018 e oferece uma bela perspectiva para a volta dos investimentos. Entretanto, pairam algumas incertezas: até quando o silêncio das ruas manter-se-á ensurdecedor? As reformas, mesmo desidratadas como a da Previdência, serão aprovadas?

No plano internacional, outra incógnita: os insultos trocados entre o loiro desvairado e o gordinho sinistro poderão resultar em um impensável conflito nuclear, empurrando o mundo para um precipício incompatível com um bom clima para os negócios? 